\title{
PENERAPAN TEKNIK STIMULUS MUTILASI DALAM BUDIDAYA KEPITING SOKA (SOFT-SHELLED CRABS) DI DESA PULAU CAWAN KABUPATEN INDRAGIRI HILIR
}

\section{APPLICATION OF MUTILATION STIMULUS TECHNIQUE IN SOFT-SHELLED CRABS CULTURE ON PULAU CAWAN VILLAGE, INDRAGIRI HILIR REGENCY}

\author{
Dwi Sushanty $^{1}$, Syaiful Ramadhan Harahap ${ }^{1 *}$, Yoyon Riono ${ }^{2}$ dan Roberta Zulfhi Surya ${ }^{3}$ \\ ${ }^{1}$ Prodi Budidaya Perairan, Fakultas Pertanian, Universitas Islam Indragiri \\ ${ }^{2}$ Prodi Agroteknologi, Fakultas Pertanian, Universitas Islam Indragiri \\ ${ }^{3}$ Prodi Teknik Industri, Fakultas Pertanian, Universitas Islam Indragiri \\ dwi.sush4nty@gmail.com; syaiful.r.harahap@gmail.com; \\ riono_yoyon@yahoo.co.id;robertazulfhi@yahoo.co.id
}

\begin{abstract}
Abstrak
Desa Pulau Cawan berada di Kabupaten Indragiri Hilir yang terkenal sebagai daerah penghasil Kepiting Bakau (Scylla serrate Forskal.). Peningkatan permintaan pasar yang diikuti dengan meningkatnya nilai ekonomis Kepiting Bakau mendorong masyarakat melakukan eksploitasi secara berlebihan sehingga dikhawatirkan akan mengancam kelestariannya. Solusi yang dapat dikembangkan adalah dengan cara budidaya Kepiting Soka. Tujuan dari pengabdian ini adalah meningkatkan pengetahuan masyarakat tentang pentingnya menjaga kondisi ekologi dan keberlanjutan kepiting bakau di alam dengan pendekatan penerapan iptek terkait budidaya kepiting soka. Kegiatan budidaya kepiting soka merupakan salah satu upaya berkelanjutan agar proses recruitment alamiah kepiting bakau dapat terus berlangsung. Penerapan iptek yang dilakukan adalah teknik stimulus mutilasi organ pada budidaya kepiting soka untuk mempercepat proses moulting dan meminimalisir biaya produksi. Kegiatan pengabdian ini dilaksanakan dengan melakukan penyuluhan, diskusi dan praktek secara langsung untuk menggali informasi tentang tingkat pengetahuan masyarakat terkait kondisi ekologi dan kelestarian kepiting bakau serta memberikan keterampilan teknis budidaya kepiting soka sebagai alternatif ekonomi yang dapat dikembangkan. Serangkaian kegiatan penyuluhan dan praktek teknis budidaya kepiting soka di respon positif oleh masyarakat nelayan Desa Pulau Cawan. Peningkatan pengetahuan dan keterampilan masyarakat melalui kegiatan pengabdian ini merupakan upaya berkelanjutan untuk tetap menjaga kelestarian kepiting bakau di alam serta dapat memberikan kontribusi pada peningkatan pendapatan masyarakat nelayan di Desa Pulau Cawan.
\end{abstract}

Kata kunci: stimulus mutilasi, kepiting soka, rekruitmen, peningkatan pendapatan

\begin{abstract}
Pulau Cawan Village located in Indragiri Hilir Regency is a mangrove crab producing area. An increase in market demand followed by an increase in the economic value of the mangrove crab triggers the community to over-exploit causing its sustainability to be disrupted. The solution offered by cultivating Softshelled crabs. The aim of the community service activity is to increase public knowledge about the ecological protection and sustainability of mangrove crabs by applying science and technology approaches to soft-shelled crabs culture. Soft-shelled crabs culture activities are ongoing efforts the mangrove crab recruitment process is sustainable. The application of science and technology is to introduce the stimulating organ mutilation in the cultivation of soft-shelled crabs to accelerate the process of moulting and minimize production costs. The community service activities are carried out with counseling, discussions and hands-on practice to gather information about community knowledge related to ecological conditions and the preservation of mangrove crabs and to provide technical skills in Soft-shelled crabs cultivation as an economic alternative that can be developed. The implementation of counseling and technical practice of soft-shelled crabs cultivation was responded positively by the fishing communities of Pulau Cawan Village. Increased knowledge and skills through community service activities is an ongoing effort to keep mangrove crabs sustainable and can contribute to increasing the income of fishing communities in Pulau Cawan Village.
\end{abstract}

Keywords: mutilation stimulus, soft-shelled crab, recruitment, increased income 


\section{PENDAHULUAN}

Pulau Cawan adalah salah satu desa di pesisir Kabupaten Indragiri Hilir dengan bentang alam yang di dominasi hutan mangrove. Secara geomorfologis Desa Pulau Cawan berbatasan langsung dengan muara Sungai Indragiri dan Selat Malaka. Perjalanan melalui Sungai Indragiri akan dijumpai vegetasi hutan nipah (Nypa fruticans Wurmb) yang berjejer menutupi sempadan sungai hingga muara. Selepas muara sungai akan dijumpai hutan mangrove memanjang mengikuti kontur garis pantai dengan jenis vegetasi Avicennia sp., Sonneratia alba, Rhizophora sp dan Bruguiera sp. Kondisi ini menjadikan Desa Pulau Cawan kaya akan sumberdaya perikanan dengan salah satu komoditas andalan Kepiting Bakau (Scylla serrata Forskal.).

Sebagaimana karakteristik masyarakat di wilayah pesisir, mayoritas masyarakat lokal di Desa Pulau cawan berprofesi sebagai nelayan tangkap, sehingga geliat kegiatan ekonomi di daerah ini sangat bergantung pada ketersediaan sumberdaya perikanan terutama dari ekosistem mangrove dan estuary. Salah satu komoditas perikanan ekonomis tinggi yang menjadi andalan dan incaran masyarakat nelayan tangkap di Desa Pulau Cawan selain udang adalah Kepiting Bakau.

Jumlah permintaan dan nilai ekonomis kepiting bakau yang terus meningkat memicu terjadinya eksploitasi secara berlebihan terhadap komoditas kepiting bakau dalam berbagai ukuran dan stadia sehingga dikhawatirkan akan mengancam kelestariannya. Hingga saat ini, masyarakat mencari dan menangkap kepiting bakau dengan metode konvensional tanpa klasifikasi. Seluruh hasil tangkapan yang terdiri dari berbagai ukuran dan tingkat usia kematangan gonad hanya dikelompokkan untuk menentukan harga dan pangsa pasar (DKP Kab Indragiri Hilir, 2019). Eksploitasi kepiting bakau secara konvensional dan tidak memperhatikan aspek keberlanjutan akan berdampak secara langsung pada terganggunya proses recruitment alamiah sehingga akan terjadi penurunan populasi dan kelangkaan. Kondisi ini pada akhirnya akan berpengaruh signifikan terhadap menurunnya pendapatan masyarakat nelayan di Desa Pulau Cawan.

Beberapa permasalahan yang dialami masyarakat nelayan tangkap di Desa Pulau Cawan yang menjadi sasaran dalam kegiatan pengabdian masyarakat ini antara lain : (1). Pengetahuan masyarakat tentang manfaat hutan mangrove/bakau bagi wilayah pesisir masih rendah sehingga eksploitasi yang dilakukan belum memperhatikan aspek keberlanjutan, (2). Pemahaman dan implementasi Per Men KPRI No. 1/PERMEN-KP/2015 dalam melakukan penangkapan kepiting bakau tergolong masih rendah sehingga penangkapan berbagai ukuran dan stadia masih dilakukan sehingga mengganggu recruitment alamiah di alam, (3). 
Berdasarkan hasil pengamatan tim, Desa Pulau Cawan sangat potensial untuk pengembangan budidaya kepiting cangkang lunak/soka (soft-shelled crabs) namun kurangnya pengetahuan dan informasi terkait teknik budidaya kepiting soka yang ramah lingkungan, efektif dan efisien menyebabkan potensi ini belum dilirik sebagai salah satu ekonomi alternatif dalam meningkatkan nilai tambah produk perikanan yang berdampak terhadap peningkatan pendapatan rumah tangga nelayan. Kegiatan pengabdian masyarakat ini merupakan upaya untuk meningkatkan pengetahuan masyarakat sekaligus dapat memberi peluang dan kontribusi untuk meningkatkan pendapatan masyarakat nelayan melalui budidaya kepiting soka.

Harianto (2017) menyatakan bahwa kepiting soka adalah kepiting bakau fase ganti kulit (moulting) sehingga memiliki cangkang yang lunak (soft carapace). Salah satu kendala yang dihadapi dalam budidaya kepiting soka adalah waktu produksi yang relatif lama (berkisar 1-4 bulan tergantung ukuran kepiting) yang disebabkan oleh lamanya durasi waktu kepiting mencapai fase moulting (Sari et al., 2019). Konsekuensi dari keadaan ini adalah biaya produksi akan meningkat. Beberapa tahun belakangan ini telah banyak dikembangkan metode/teknik untuk mempercepat proses moulting pada kegiatan budidaya kepiting soka, diantaranya adalah dengan melakukan stimulus mutilasi terhadap sebahagian organ kepiting. Teknik mutilasi yang banyak dilakukan adalah dengan melakukan pemotongan ujung organ capit dan sebahagian kaki jalan guna merangsang terjadinya proses moulting. Stimulus ini dilakukan karena diketahui bahwa pada kaki jalan dan capit kepiting banyak terdapat hormon penghambat moulting atau dikenal dengan istilah molt inhibiting hormone (Harahap, et al., 2016; Harianto, 2017).

Tujuan dari kegiatan pengabdian ini adalah untuk meningkatkan pengetahuan dan keterampilan masyarakat nelayan tangkap dalam memanfaatkan hutan mangrove dan kepiting bakau secara berkelanjutan. Pendekatan yang dilakukan adalah penerapan iptek berupa teknik budidaya kepiting soka yang efektif dan efisien. Teknik yang dimaksud adalah penerapan teknik stimulus mutilasi organ untuk mempercepat proses moulting yang akan berpengaruh kepada laju pertumbuhan kepiting bakau. Peningkatan pengetahuan dan keterampilan masyarakat melalui kegiatan pengabdian ini diharapkan memberikan manfaat berupa peningkatan pengetahuan masyarakat nelayan tangkap dalam memanfaatkan mangrove dan kepiting bakau secara berkelanjutan sekaligus memberikan peluang ekonomi alternatif untuk meningkatkan pendapatan masyarakat nelayan tangkap di Desa Pulau Cawan melalui kegiatan budidaya kepiting soka. 


\section{METODOLOGI}

Seluruh rangkaian kegiatan pengabdian masyarakat ini dilaksanakan selama 5 (lima) bulan yaitu Maret-Juli 2019. Lokasi pengabdian berada di Desa Pulau Cawan Kecamatan Mandah Kabupaten Indragiri Hilir Propinsi Riau dengan letak geografis berada pada Latitude 103.56100 dan Longitude -0.094146. Jarak tempuh dari Ibukota Kabupaten (Kota Tembilahan) ke Desa Pulau Cawan $\pm 75 \mathrm{~km}$ dengan waktu tempuh selama \pm 2 jam menggunakan moda transportasi laut (speedboat) yang merupakan satu-satunya moda transportasi yang tersedia.

Kegiatan pengabdian ini dilaksanakan dengan beberapa metoda pendekatan antara lain penyuluhan, sosialisasi, diskusi dan wawancara secara mendalam (In-depth interview) serta praktek langsung tentang penerapan teknis stimulus mutilasi dalam budidaya kepiting soka kepada masyarakat nelayan di Desa Pulau Cawan. Kegiatan dimulai dengan melakukan pemantauan kondisi awal kualitas perairan dan pemilihan lokasi yang representatif untuk budidaya kepiting soka yang di ikuti dengan pembuatan demplot pada lokasi yang representatif berdasarkan kondisi lingkungan perairan.

Kegiatan penyuluhan, sosialisasi, diskusi dan wawancara secara mendalam (In-depth interview) dilaksanakan di balai Desa Pulau Cawan, dengan memberi sosialisasi tentang konsep pemanfaatan kepiting bakau secara berkelanjutan yang disesuaikan dengan Per Men Kelautan dan Perikanan Nomor : 1/PERMEN-KP/2015 tentang kegiatan penangkapan lobster (Panulirus spp.), kepiting bakau (Scylla serrata) dan rajungan (Portunus pelagicus spp.). Kegiatan penyuluhan dilanjutkan diskusi dan praktek teknis stimulus mutilasi untuk mempercepat proses moulting sehingga dapat mempercepat proses pembesaran dan meminimalisir biaya produksi. Kegiatan penyuluhan dan praktek juga bertujuan untuk menggali informasi tentang tingkat pemahaman masyarakat terhadap kegiatan budidaya kepiting soka sebagai alternatif dalam meningkatkan pendapatan rumah tangga. Seluruh rangkaian kegiatan penyuluhan, sosialisasi, diskusi dan praktek budidaya kepiting soka di hadiri oleh aparatur desa, dua orang tokoh masyarakat dan lima kepala rumah tangga nelayan Desa Pulau Cawan.

\section{PEMBAHASAN}

Kegiatan penerapan stimulus mutilasi dalam budidaya kepiting soka kepada masyarakat nelayan di Desa Pulau Cawan Kabupaten Indragiri Hilir dilaksanakan melalui beberapa tahapan. Capaian setiap tahapan kegiatan pengabdian dijelaskan sebagai berikut: 


\section{Pemantauan Kondisi Awal Kualitas Perairan dan Pemilihan Lokasi Demplot}

Pemantauan kondisi awal kualitas perairan dan pemilihan lokasi demplot dilaksanakan dengan survey lapangan ke Desa Pulau Cawan untuk mendapatkan gambaran kondisi eksisting lokasi yang akan dijadikan pusat kegiatan pengabdian. Pada tahapan ini dilakukan diskusi bersama beberapa tokoh masyarakat dan aparatur desa terkait status kepemilikan lahan yang akan dijadikan demplot kegiatan budidaya kepiting soka. Selanjutnya dilakukan penilaian terhadap kelayakan lokasi dengan mengukur beberapa parameter kualitas fisika dan kimia perairan yang akan dijadikan demplot kegiatan budidaya kepiting soka. Hasil pemantauan terhadap kelayakan lokasi demplot dapat dilihat pada Tabel 1.

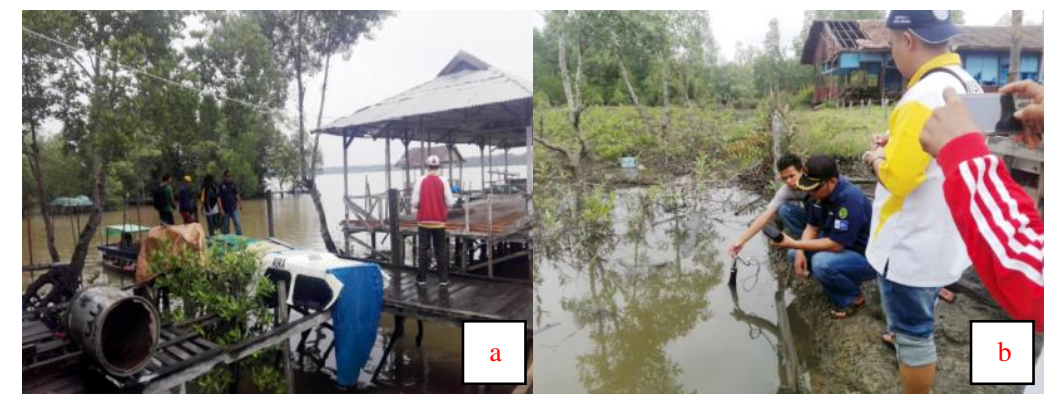

Figur 1. Survey lokasi demplot (a) dan pemantauan awal kondisi kualitas perairan di lokasi rencana demplot (b)

Tabel 1. Kelayakan lokasi demplot budidaya kepiting soka ditinjau dari parameter kualitas air

\begin{tabular}{lcc}
\hline Parameter & $\begin{array}{c}\text { Kisaran } \\
\text { Optimal }\end{array}$ & $\begin{array}{c}\text { Kisaran Kualitas Perairan } \\
\text { Desa Pulau Cawan }\end{array}$ \\
\hline Oksigen terlarut $(\mathrm{mg} / \mathrm{L})$ & $>5$ & $5,24-5,91$ \\
$\mathrm{pH}$ & $7,5-9,0$ & $6,90-7,09$ \\
Suhu $\left({ }^{\circ} \mathrm{C}\right)$ & $25-30$ & $29,30-29,80$ \\
Salinitas $(\mathrm{ppt})$ & $25-35$ & $21,0-21,8$ \\
Kekeruhan $(\mathrm{cm})$ & $20-30$ & $20,5-21,1$ \\
Kedalaman $(\mathrm{cm})$ & $80-120$ & $83-118$ \\
\hline
\end{tabular}

Sumber: ${ }^{*}$ Shelley dan Lovatelli (2011); ${ }^{* *}$ Hasil Pengukuran Lapangan (2019).

Hasil survey kelayakan lokasi demplot budidaya kepiting soka yang ditinjau dari beberapa parameter kualitas air diketahui bahwa seluruh parameter kualitas perairan masih berada dalam kisaran optimal berdasarkan Shelley dan Lovatelli (2011) dan masih mendukung untuk pengembangan kegiatan budidaya kepiting soka.

Menurut Fujaya, et al. (2019) suhu merupakan salah satu faktor abiotik penting yang mempengaruhi aktivitas kelangsungan hidup, pertumbuhan dan moulting krustasea. Suhu air yang lebih rendah dari $20^{\circ} \mathrm{C}$ akan mengakibatkan aktifitas dan nafsu makan kepiting bakau menurun secara drastis, pertumbuhan akan berhenti walaupun kepiting masih dapat tetap 
hidup (Baliao dalam Katiandagho, 2014). Sedangkan perairan dengan suhu yang relatif tinggi cenderung akan meningkatkan pertumbuhan dan memperpendek masa interval moulting krustasea. Diantara faktor-faktor lingkungan lainnya, suhu merupakan faktor yang paling berpengaruh pada pertumbuhan dan moulting (Hoang dalam Aslamyah dan Fujaya, 2014).

Sara (1994) menerangkan bahwa salinitas dapat mempengaruhi struktur dan fungsi organ organisme perairan melalui perubahan tekanan osmotik yang dapat merubah komposisi spesies pada situasi ekologis saat itu. Salinitas merupakan salah satu faktor lingkungan yang berpengaruh penting pada konsumsi pakan, metabolisme, sintasan dan pertumbuhan organism akuatik. Salinitas merupakan masking factor yang dapat memodifikasi peubah fisika dan kimia air menjadi satu kesatuan pengaruh yang berdampak osmotik pada osmoregulasi dan bioenergetik (Karim, 2005).

Oksigen terlarut (Dissolved Oxygen) pada dasarnya dibutuhkan oleh semua jasad hidup untuk proses respirasi, metabolisme atau pertukaran zat yang kemudian menghasilkan energi untuk pertumbuhan dan pembiakan. Menurut Christensen dalam Sagala, et al. (2013) pada dasarnya kepiting bakau dapat hidup pada lingkungan perairan dengan kisaran oksigen 2,65-4,00 mg/L. Kebutuhan oksigen terlarut minimum untuk Kepiting Bakau adalah 4,0 $\mathrm{mg} / \mathrm{L}$, sedangkan konsentrasi oksigen terlarut untuk pertumbuhan yang paling baik adalah $>5$ mg/l (Mwaluma dalam Katiandagho, 2014).

\section{Pembuatan Demplot}

Demplot budidaya kepiting soka berada pada kawasan hutan mangrove yang masih dipengaruhi oleh pasang surut laut. Ukuran demplot budidaya kepiting soka PxLxT $(5 \times 3 \times 1,5$ $\mathrm{m}^{2}$ ). Selanjutnya dilakukan pengeringan dasar demplot yang dilanjutkan dengan kegiatan pembersihan serta pemberantasan hama menggunakan saponin.
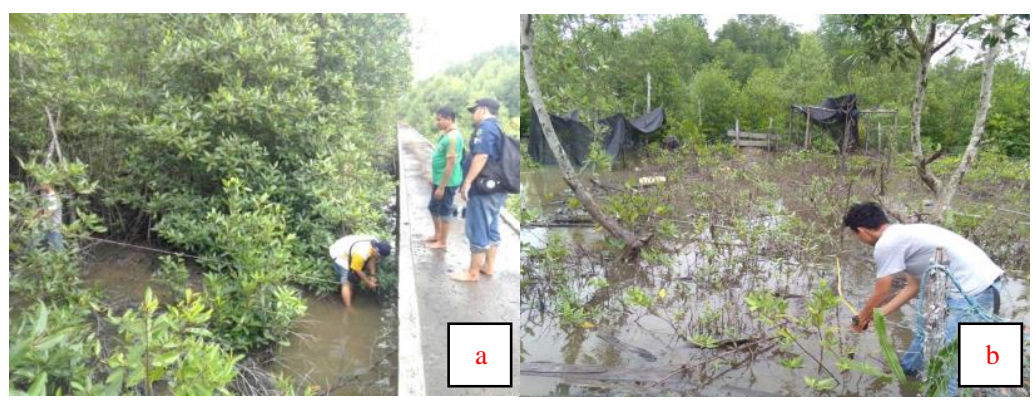

Figur 2. Pembuatan demplot (a) dan kegiatan pengeringan, pembersihan serta pemberantasan hama menggunakan saponin (b) 


\section{Sosialisasi Kegiatan}

Sosialisasi kegiatan pengabdian kepada kelompok masyarakat nelayan dilakukan dengan cara bertatap muka langsung menggunakan pendekatan teknik komunikasi persuasif dan informatif dengan tujuan agar mitra sasaran dapat mengerti dan memahami (to secure understanding) materi yang diberikan. Sosialisasi dilakukan dalam bentuk ceramah (penyuluhan) di balai Desa Pulau Cawan. Materi sosialisasi meliputi berbagai pengetahuan mengenai pentingnya menjaga hutan mangrove, Per Men Kelautan dan Perikanan Nomor : 1/PERMEN-KP/2015, budidaya kepiting soka dalam karamba dan faktor-faktor yang mempengaruhinya, serta materi tentang penerapan teknis stimulus mutilasi dalam mempercepat proses pembesaran dan meminimalisir biaya produksi. Pada tahapan ini tim dan mitra lebih banyak membuka diskusi terkait materi yang disampaikan, sehingga dapat diketahui tingkat pemahaman dan tanggapan sasaran terkait materi yang diberikan. Deskripsi mengenai tingkat pemahaman masyarakat nelayan selanjutnya dijadikan dasar dalam memilih 2 (dua) orang yang akan dijadikan mitra pelaksana/pengelola kegiatan budidaya kepiting soka.

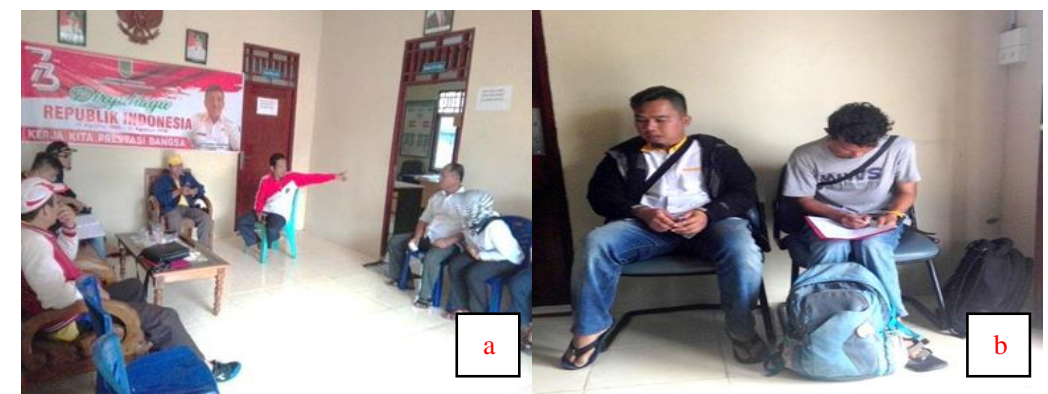

Figur 3. Sosialisasi dan penyuluhan tentang budidaya kepiting soka (a) dan penandatanganan persetujuan mitra kegiatan pengabdian (b)

\section{Pendampingan dan Penerapan Iptek}

Kegiatan pendampingan penerapan iptek budidaya kepiting soka meliputi: pemilihan bibit, penerapan iptek stimulus mutilasi pada organ capit dan kaki jalan kepiting, penebaran, pembuatan dan pemberian pakan, pengelolaan kualitas air, pemantauan pertumbuhan dan kelulushidupan serta pengawasan dan panen.

\section{Pemilihan bibit}

Pemilihan bibit mempertimbangkan kriteria bibit yang baik dan diperkirakan akan moulting dalam waktu yang tidak begitu lama dengan memperhatikan ciri-ciri berikut: gerakannya aktif dan gesit, bagian tubuhnya lengkap, warna cerah/normal tidak pucat/pudar, bobot berkisar antara 80-150 g per ekor (Iromo, et al., 2019). 


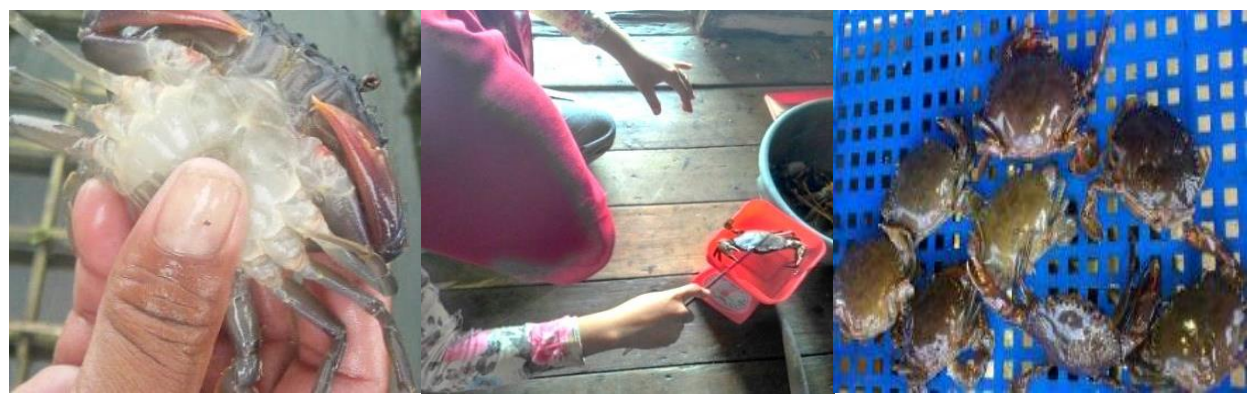

Figur 4. Pemilihan bibit kepiting bakau

Bibit kepiting dengan kisaran berat 80-150 g merupakan bobot rata-rata kepiting muda, dimana proses moultingnya relatif akan lebih cepat dibandingkan bibit dengan berat lebih dari $150 \mathrm{~g}$. Selain itu pada bobot tersebut umumnya kepiting belum termasuk dalam katagori induk yang tidak akan moulting. Hal ini sesuai dengan Sulaeman dalam Iromo, et al. (2019) bahwa moulting kepiting pada ukuran yang lebih kecil biasanya lebih cepat, maka pengembangan kepiting soka diarahkan untuk kepiting muda dengan bobot 60-150 g/ekor. Bibit kepiting yang digunakan dalam kegiatan pengabdian ini semuanya berjenis kelamin jantan. Pengunaan kepiting jantan bertujuan agar kegiatan budidaya kepiting soka tidak mengganggu recruitment kepiting bakau di alam, karena kepiting betina yang memiliki ukuran sekitar 150 gram merupakan kepiting yang telah berkembang telurnya dan tidak akan moulting (Iromo, et al., 2019).

\section{Penerapan stimulus mutilasi organ}

Teknik mutilasi menjadi cara yang paling praktis untuk mempercepat terjadinya moulting serta dapat diterapkan secara massal. Dengan memotong bagian-bagian tertentu dari organ tubuh kepiting, maka akan memacu hormon pertumbuhan untuk membentuk kembali anggota badan yang hilang. Cara ini dapat menjadikan kepiting muda dapat berganti kulit dalam kurun waktu 2-3 minggu tergantung pada ketelitian dalam memilih kepiting yang telah mendekati fase moulting (Ario, et al., 2019).

Sebelum proses stimulus mutilasi dilakukan, kepiting terlebih dahulu diaklimatisasi dengan air yang terdapat pada demplot dengan cara mencelupkan kepiting ke dalam air selama beberapa saat. Setelah kepiting nampak segar, dilakukan stimulus mutilasi yaitu dengan melakukan pemotongan terhadap organ ujung capit dan sebahagian kaki jalan kepiting dengan menggunakan tang/gunting/pisau (Harianto, 2017). Stimulus mutilasi organ dilakukan dengan tujuan untuk menghambat perkembangan hormon MIH (molt inhibiting hormone) sehingga dapat mempercepat proses terjadinya moulting pada kepiting (Harahap, et al., 2016; Harianto, 2017). 


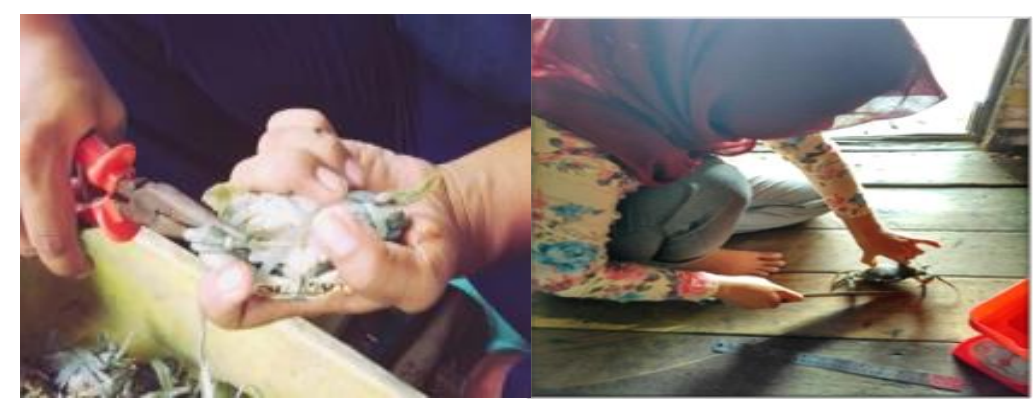

Figur 5. Stimulus mutilasi pada organ ujung capit dan kaki jalan kepiting bakau

Secara biologis pemotongan capit dan kaki jalan dapat merangsang organ tubuh kepiting untuk tumbuh kembali (Affandi dan Tang, 2002). Setelah capit dan kaki jalan kepiting lepas, kepiting akan terangsang untuk memperbaiki fungsi morfologi tubuhnya dengan cara melakukan pergantian kulit sehingga akan terbentuk bagian tubuh yang baru berupa kepiting yang bercangkang lunak/soka (Widyastuti dan Husni, 2007). Teknik mutilasi merupakan upaya untuk meningkatkan produk kepiting soka karena dapat merangsang keluarnya hormon exdecis untuk memicu moulting dengan cepat (Ariani, et al., 2018). Hormon yang menghambat kepiting bakau moulting terletak pada organ gerak kepiting bakau (Samidjan dan Rachmawati, 2015).

\section{Penebaran}

Setelah tahapan mutilasi organ dilakukan, kepiting di tebar ke dalam crab box berbentuk segi empat secara individual. Crab box yang berisi kepiting diikatkan pada rakit bambu berdiameter satu inci yang memiliki sekat-sekat, sehingga membentuk kamar-kamar. Tiap rakit di isi dengan 9 unit crab box yang telah diatur rapi agar mudah di kontrol selama proses pemeliharaan. Pada tiap ujung rakit diikatkan tiang-tiang dari bambu agar rakit tidak tenggelam dan terbawa arus ketika terjadi proses pasang surut. Selanjutnya crab box pada rakit diapungkan dan ditenggelamkan sedalam $15 \mathrm{~cm}$ ke dalam air (Harianto, 2017).

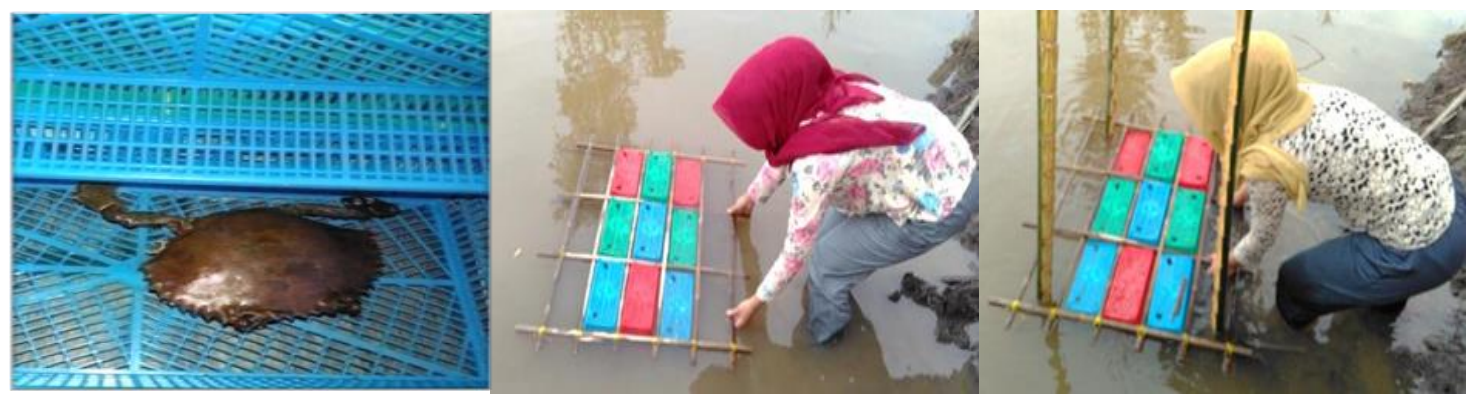

Figur 6. Teknik penebaran kepiting pada rangkaian crab box pada rakit 
4. Pembuatan dan pemberian pakan

Pakan yang digunakan berupa pakan alami yaitu ikan rucah yang berasal dari hasil sampingan tangkapan nelayan di sekitar perairan Pulau Cawan. Ikan rucah yang digunakan sebagai pakan pada kegiatan pengabdian ini di potong/di cincang kecil-kecil dengan ukuran 1-2 cm. Frekuensi pemberian pakan merujuk pada Ario, et al. (2019) dan Fujaya, et al. (2019) dengan frekuensi pemberian pakan satu kali sehari pada sore hari antara pukul 15.0016.00 WIB. Proporsi pakan yang diberikan sebesar 20\% dari berat tubuh kepiting (Muchlisin dalam Wicaksono, et al., 2014).

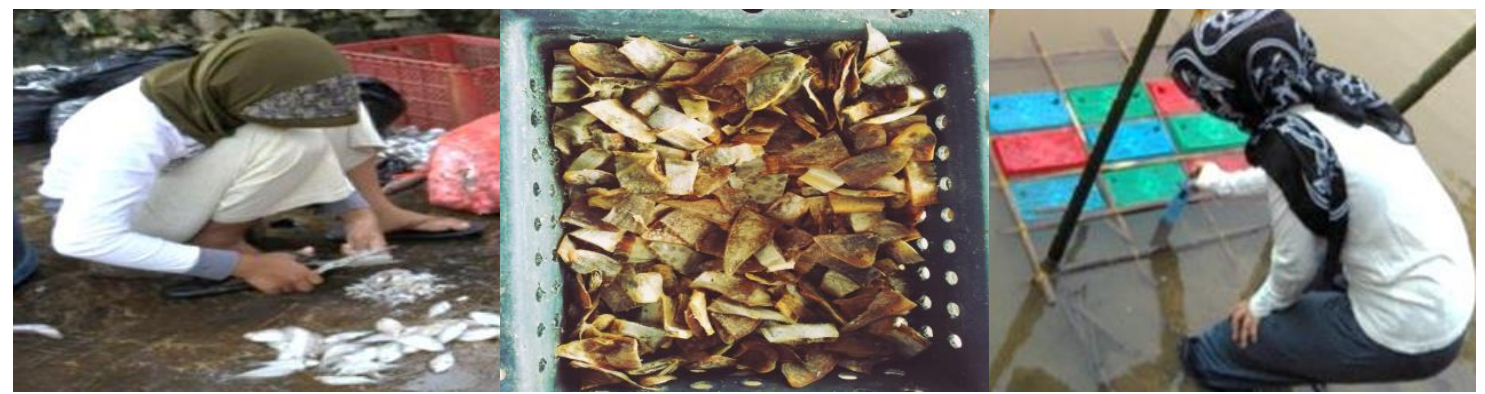

Figur 7. Proses pembuatan pakan dan pemberian pakan kepiting

Penggunaan ikan rucah pada kegiatan pengabdian ini selain karena disukai kepiting juga karena kandungan nutrisinya yang variatif, mudah dicerna dan sesuai kebiasaan makan kepiting. Septian, et al. (2013) menyatakan bahwa ikan rucah sebagai pakan bersifat mudah tenggelam sehingga peluang untuk dimakan kepiting lebih besar karena kepiting lebih suka mencari makanan pada dasar perairan. Selain itu ikan rucah memiliki daging yang empuk sehingga kepiting bakau mudah untuk memotong dan merobeknya.

\section{Pengelolaan kualitas air}

Pengelolaan kualitas air pada demplot dilakukan dengan memantau nilai parameter suhu, $\mathrm{pH}$, kandungan oksigen terlarut (DO), salinitas dan kekeruhan. Hasil pemantauan didapati bahwa nilai parameter suhu selama kegiatan berkisar 29,30-29,80 ${ }^{\circ} \mathrm{C}$, pH 6,90-7,09, DO 5,24-5,91 mg/L, salinitas 21,0-21,8 ppt dan kekeruhan 20,5-21,1 cm.

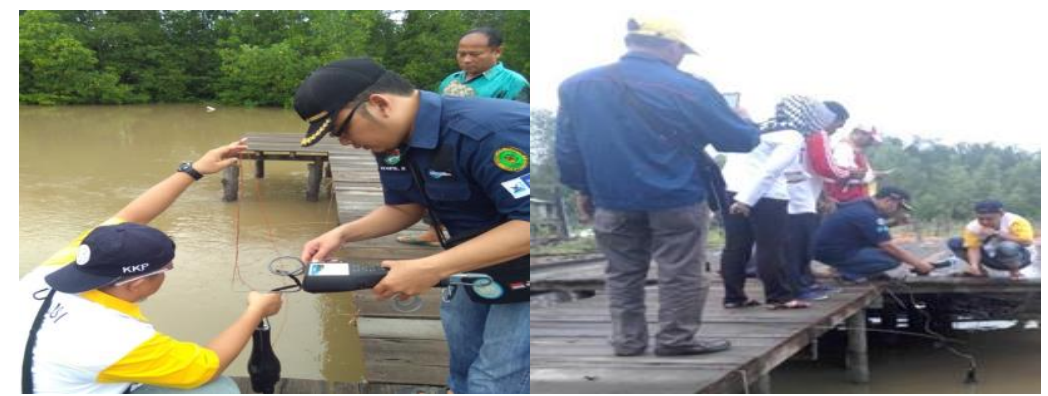

Figur 8. Pemantauan kualitas air pada demplot 
Menurut Fujaya, et al. (2019) suhu optimum untuk pertumbuhan kepiting adalah $25^{\circ} \mathrm{C}-35^{\circ} \mathrm{C}$ dan derajat keasaman $(\mathrm{pH})$ dalam media budidaya kepiting bakau sebaiknya dipertahankan antara 6,5-8,5 (Rangka, 2007). Kepiting bakau bersifat euryhaline atau dapat hidup dengan kisaran salinitas yang lebar dalam budidaya, menurut Kathirvel dalam Wicaksono, et al. (2014), salinitas yang diperlukan yaitu berkisar antara 10-35 ppt. Level DO sebaiknya dipertahankan di atas 5 ppm atau $5 \mathrm{mg} / \mathrm{L}$ (Shelley dan Lovatelli, 2011). Hal ini menunjukkan bahwa kisaran nilai beberapa parameter kualitas air pada demplot budidaya masih mendukung pertumbuhan optimal kepiting.

\section{Pemantauan pertumbuhan dan kelulushidupan}

Pemantauan pertumbuhan dilakukan dengan cara mengukur diameter kepiting dan melakukan penimbangan berat. Sedangkan kelulushidupan dilihat dari persentase jumlah kepiting yang hidup hingga panen dilakukan. Hasil pengukuran laju pertumbuhan, moulting dan kelulushidupan kepiting selama kegiatan dapat dilihat pada Tabel 2.

Tabel 2. Laju pertumbuhan dan kelulushidupan kepiting selama kegiatan

\begin{tabular}{|c|c|c|c|c|}
\hline \multicolumn{4}{|c|}{ Laju Pertumbuhan } & \multirow{3}{*}{$\begin{array}{l}\text { SR } \\
(\%)\end{array}$} \\
\hline \multicolumn{2}{|c|}{ Berat (gram) } & \multicolumn{2}{|c|}{ Lebar $(\mathrm{cm})$} & \\
\hline $\mathrm{W}_{0}$ & $\mathrm{~W}_{\mathrm{t}}$ & $\mathrm{L}_{0}$ & $\mathrm{~L}_{\mathrm{t}}$ & \\
\hline $103,3 \pm 6,6$ & $130,0 \pm 6,2$ & $5,6 \pm 0,1$ & $6,6 \pm 0,2$ & 100 \\
\hline
\end{tabular}

Keterangan: $\mathrm{W}_{0}=$ Berat awal kepiting $(\mathrm{gram}) ; \mathrm{W}_{\mathrm{t}}=$ Berat akhir kepiting $(\mathrm{cm}) ; \mathrm{L}_{0}=$ Lebar cangkang awal kepiting $(\mathrm{cm}) ; \mathrm{L}_{\mathrm{t}}=$ Lebar cangkang akhir kepiting (cm); SR = Kelulushidupan kepiting $(\%)$.

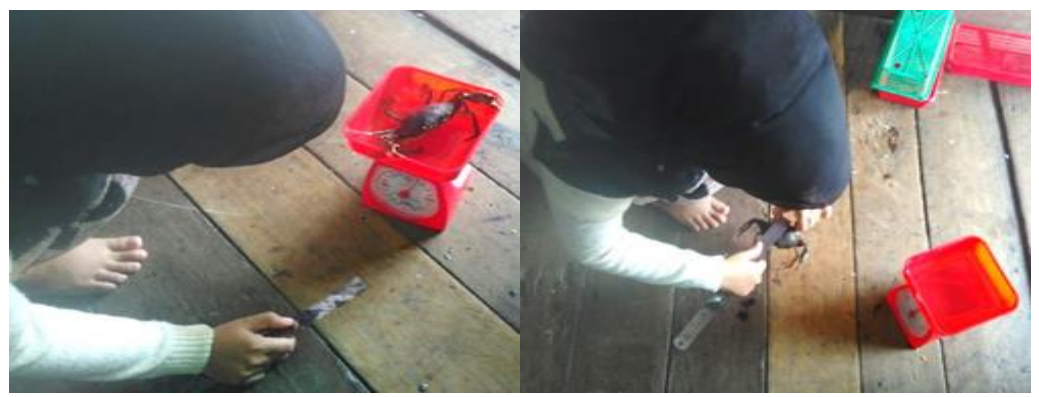

Figur 9. Pengukuran laju pertumbuhan kepiting

Hasil pemantauan laju pertumbuhan selama kegiatan diperoleh pertambahan berat rata-rata kepiting selama kegiatan berlangsung adalah 26,8 $\pm 6,4$ gram dengan pertambahan lebar carapace rata-rata 1,0 $\pm 0,15 \mathrm{~cm}$ dengan tingkat kelulushidupan (SR) 100\%. Hasil yang lebih baik ditunjukkan oleh Wicaksono, et al. (2014) dimana pemberian pakan cincangan ikan rucah menghasilkan pertambahan berat antara 38,1-50,4 g dengan rata-rata berat sebesar 44,0 $\pm 5,1$ g. Menurut Rangka (2010), pada saat molting, air akan terakumulasi ke dalam darah dan kantung-kantung air dalam tubuh kepiting untuk membantu merentangkan cangkang 
yang masih lunak menjadi bentuk yang lebih besar. Secara keseluruhan, penambahan bobot pada setiap fase moulting berkisar antara 3\%-44\%. Penjelasan ini menunjukkan bahwa semakin sering kepiting bakau melakukan molting maka akan bertambah berat tubuhnya (Rusmiyati, 2011).

Pertumbuhan juga sangat dipengaruhi jenis pakan. Pada kegiatan ini, ikan rucah dijadikan sebagai pakan alami. Pemberian ikan rucah sebagai pakan dapat menghasilkan pertumbuhan kepiting yang optimal. Hal ini diduga karena ikan rucah memiliki unsur nutritif yang lebih bervariatif, sehingga deposit kandungan nutrisi pada tubuh kepiting bakau sesuai dengan kebutuhan dan siklus hidupnya (Wicaksono, et al., 2014). Deposit nutrisi digunakan selama fase intermolt. Chen (1992) menyatakan bahwa selama fase intermolt, eksoskeleton menjadi semakin keras melalui mineral dan protein yang terdeposit. Protein pada ikan rucah lebih mudah dicerna oleh kepiting. Protein hewani lebih mudah dicerna dengan kandungan asam amino yang lebih lengkap dibanding protein nabati (Fujaya, et al., 2019).

Tingkat kelulushidupan kepiting pada kegiatan pengabdian ini sangat tinggi dengan nilai (SR) 100\%. Menurut Kudsiah, et al. (2018), tingkat kelulushidupan di atas $80 \%$ pada budidaya kepiting soka sudah dikategorikan tinggi. Tingkat kelulushidupan dipengaruhi oleh faktor biotik dan abiotik. Faktor biotik terdiri dari umur dan kemampuan kepiting dalam menyesuaikan diri dengan lingkungan, sedangkan faktor abiotik antara lain ketersediaan makanan dan kualitas media hidup (Watanabe dalam Qomariyah, et al., 2014). Ketersediaan makanan berupa ikan rucah dalam kegiatan pengabdian ini diduga cukup untuk memenuhi kebutuhan kepiting, serta kualitas air pada demplot budidaya masih dalam kisaran optimal dalam mendukung peningkatan kelulushidupan kepiting bakau.

\section{Pengawasan dan Panen}

Pengawasan dalam kegiatan budidaya kepiting soka sangat menentukan kualitas kepiting yang akan dihasilkan. Kegiatan pengawasan dilakukan secara rutin setiap 2-3 jam. Apabila di dalam crab box terlihat ada 2 kepiting, maka itu adalah indikator bahwa kepiting telah berganti kulit (moulting). Secara normal, rata-rata kepiting akan moulting setiap 50 hari dan biasanya terjadi pada malam hari, namun dengan penerapan iptek stimulus mutilasi dengan melakukan pemotongan ujung capit dan sebahagian kaki jalan didapati bahwa ratarata kepiting pada wadah budidaya pada kegiatan pengabdian ini moulting pada hari ke-23. Didapati juga bahwa waktu moulting pada masing-masing wadah sangat berfluktuasi yaitu terjadi pada pagi, siang, sore maupun malam hari. Hal ini menunjukkan bahwa penerapan iptek stimulus mutilasi dalam kegiatan budidaya kepiting soka dapat mempersingkat waktu 
moulting kepiting yaitu 27 hari lebih cepat dibandingkan dengan waktu moulting kepiting secara normal (alamiah). Selama masa pertumbuhan, kepiting akan mengalami pergantian kulit (moulting) antara 17-20 kali tergantung kondisi lingkungan dan pakan yang dapat mempengaruhi pertumbuhan (Rangka dan Sulaeman, 2010).

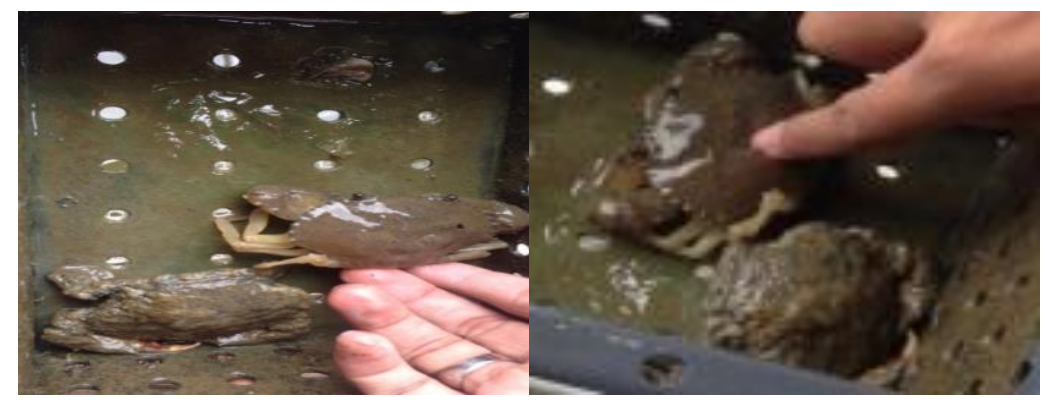

Figur 10. Proses moulting pada kepiting bakau

Proses moulting di kontrol oleh beberapa faktor eksternal dan internal. Menurut Rusmiyati (2011), faktor eksternal yang mempengaruhi moulting antara lain kualitas air dan jenis pakan yang dikonsumsi. Faktor tersebut akan mempengaruhi otak dan menstimulasi organ-Y untuk menghasilkan Ecdysteroid atau molting hormone (Lockwood dalam Fujaya et al., 2019). Hormon Ecdysteroid ini disekresi oleh organ-Y dalam bentuk ecdysone. Hormon ini dikonversi di dalam hemolimph oleh enzim 20-hydroxylase yang terdapat di epidermis organ dan jaringan tubuh lainnya menjadi hormon aktif 20-OH-ecdysone. Peningkatan level ekdisteroid dalam hemolimph tersebut adalah sinyal bagi tubuh untuk memulai proses molting (Fujaya, et al., 2019).

Penggunaan pakan yang tepat dalam kegiatan budidaya kepiting juga menjadi faktor penting dalam proses moulting. Hasil pengamatan Wicaksono, et al. (2014) memperlihatkan bahwa jumlah moulting pada kepiting bakau yang diberi pakan ikan rucah menunjukkan jumlah moulting lebih banyak dibandingkan dengan jenis pakan lainnya. Hal ini diduga protein yang terdapat pada ikan rucah dimanfaatkan dengan baik oleh kepiting bakau untuk moulting.

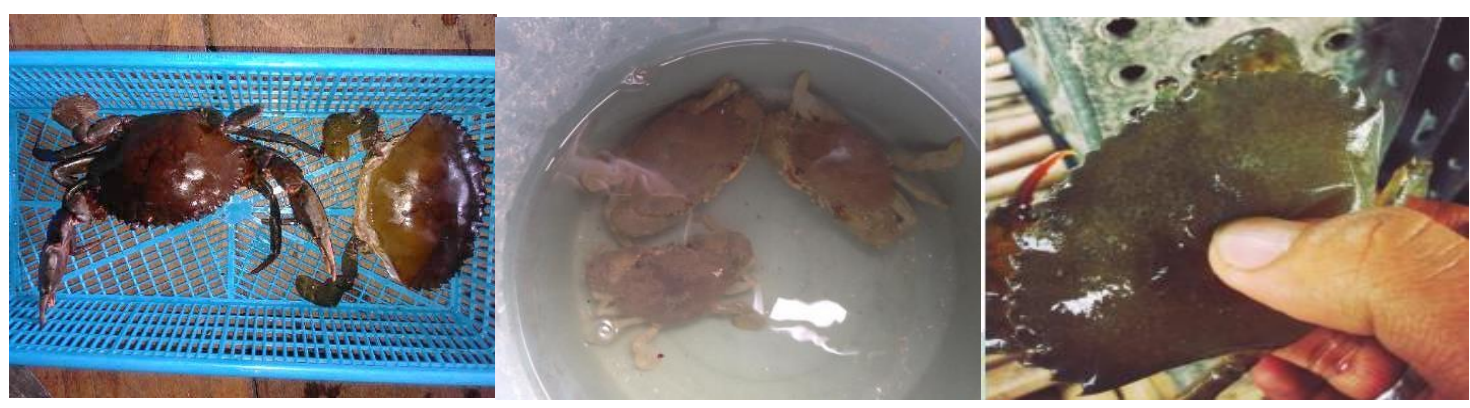

Figur 11. Proses panen kepiting soka 
Pemanenan kepiting dilakukan secara selektif, yaitu hanya kepiting yang sesuai dengan ukuran pasar yang di panen. Sedangkan kepiting yang belum sesuai ukuran pasar dikembalikan ke demplot untuk kembali dipelihara. Kegiatan panen dilakukan dengan mengangkat kepiting dari demplot, kemudian kaki dan capitnya di ikat agar tidak saling mencapit. Selanjutnya, kepiting di rendam ke dalam air tawar (air hujan) dengan durasi waktu \pm 1 jam agar kepiting bersih dari berbagai kontaminan sekaligus mereduksi garam dalam tubuh kepiting yang dapat menyebabkan carapace kembali mengeras. Rangka dan Sulaeman (2010) menyatakan bahwa pengerasan carapace membutuhkan waktu \pm 4 jam setelah proses moulting. Pengerasan kulit terjadi akibat absorpsi mineral dan proses enzimatis yang terjadi dalam tubuh kepiting (Suswanto dan Munir, 2018). Selanjutnya kepiting ditimbang, dikemas dan diawetkan dengan cara dibekukan dalam freezer (Shelley dan Lovatelli, 2011).

\section{Evaluasi Kegiatan}

Evaluasi kegiatan dilakukan setelah seluruh rangkaian sosialisasi dan penyuluhan selesai dilaksanakan. Evaluasi dilakukan dengan menggunakan kuisioner kepada 9 orang peserta kegiatan. Variabel pertanyaan kuisioner disusun berdasarkan materi penyuluhan dengan tujuan untuk melihat sejauhmana tingkat pengetahuan dan antusiasme peserta terhadap materi yang telah diberikan. Kriteria interpretasi kuisioner yang digunakan untuk evaluasi menggunakan skala likert dengan kriteria Sangat Rendah (skor 1), Rendah (skor 2), Sedang (skor 3), Tinggi (skor 4) dan Sangat Tinggi (skor 5). Hasil evaluasi terhadap mitra selama mengikuti kegiatan penyuluhan dapat dilihat pada Tabel 3.

Tabel 3. Hasil evaluasi terhadap mitra selama mengikuti kegiatan penyuluhan

\begin{tabular}{|c|c|c|c|c|c|c|c|c|c|c|c|c|c|}
\hline \multirow{3}{*}{ Variabel } & \multicolumn{13}{|c|}{ Kriteria Interpretasi } \\
\hline & \multicolumn{2}{|c|}{ SR } & \multicolumn{2}{|r|}{$\mathrm{R}$} & \multicolumn{2}{|r|}{$S$} & \multicolumn{2}{|r|}{$\mathrm{T}$} & \multicolumn{2}{|c|}{ ST } & \multicolumn{3}{|c|}{ Total } \\
\hline & $\mathrm{n}$ & skor & $\mathrm{n}$ & skor & $\mathrm{n}$ & skor & $\mathrm{n}$ & skor & $\mathrm{n}$ & skor & $\mathrm{n}$ & skor & rerata \\
\hline $\begin{array}{l}\text { Pengetahuan tentang manfaat } \\
\text { hutan mangrove/bakau bagi } \\
\text { wilayah pesisir }\end{array}$ & 0 & 0 & 0 & 0 & 4 & 12 & 3 & 12 & 2 & 10 & 9 & 34 & 3,78 \\
\hline $\begin{array}{l}\text { Pengetahuan tentang Per Men } \\
\text { KPRI No. 1/PERMEN-KP/2015 } \\
\text { tentang ketentuan penangkapan } \\
\text { kepiting bakau }\end{array}$ & 0 & 0 & 0 & 0 & 2 & 6 & 4 & 16 & 3 & 15 & 9 & 37 & 4,11 \\
\hline $\begin{array}{l}\text { Pengetahuan tentang budidaya } \\
\text { kepiting soka }\end{array}$ & 0 & 0 & 0 & 0 & 1 & 3 & 5 & 20 & 3 & 15 & 9 & 38 & 4,22 \\
\hline $\begin{array}{lrr}\begin{array}{l}\text { Pengetahuan } \\
\text { stimulus }\end{array} \text { mutilasi } & \text { teknik } \\
\text { mempercepat } & \text { moulting } & \end{array}$ & 0 & 0 & 0 & 0 & 2 & 6 & 6 & 24 & 1 & 5 & 9 & 35 & 3,89 \\
\hline Antusiasme peserta & 0 & 0 & 0 & 0 & 1 & 3 & 3 & 12 & 5 & 25 & 9 & 40 & 4,44 \\
\hline
\end{tabular}


Hasil pengamatan terhadap hasil evaluasi terhadap peserta penyuluhan menunjukkan bahwa nilai rerata kriteria interpretasi dari masing-masing variabel berada dalam rentang nilai skor 3,78 - 4,44 dengan nilai rata-rata skor interpretasi dari seluruh variabel yang di evaluasi sebesar 4,09. Hal ini menunjukkan bahwa tingkat pengetahuan dan antusiasme peserta terhadap variabel penyuluhan yang diberikan berada dalam kategori Tinggi. Kondisi ini memiliki arti bahwa peserta kegiatan memberikan respon positif terhadap kondisi ekologis dan kelestarian kepiting bakau serta sangat antusias untuk mendapatkan bekal pengetahuan tentang budidaya kepiting soka serta langkah-langkah pengelolaan yang perlu dilakukan agar kegiatan ini dapat menjadi salah satu alternatif untuk meningkatkan pendapatan masyarakat khususnya masyarakat nelayan di Desa Pulau Cawan.

\section{KESIMPULAN DAN SARAN}

Serangkaian kegiatan pengabdian yang dilakukan mengenai penerapan teknik stimulus mutilasi dalam budidaya kepiting soka dapat diterima dengan sangat baik oleh masyarakat nelayan yang ada di Desa Pulau Cawan. Evaluasi terhadap materi-materi penyuluhan dan penerapan Iptek yang diberikan menunjukkan nilai interpretasi yang tinggi terhadap peningkatan pengetahuan dan keterampilan masyarakat nelayan tangkap di Desa Pulau Cawan setelah pelaksanaan kegiatan pengabdian. Peningkatan pengetahuan dan keterampilan masyarakat terkait teknik budidaya kepiting soka tidak hanya bermanfaat terhadap keberlanjutan proses recruitment kepiting bakau di alam, tetapi juga membuka peluang pengembangan alternatif ekonomi yang dapat meningkatkan pendapatan masyarakat nelayan Desa Pulau Cawan dari kegiatan budidaya kepiting soka.

\section{UCAPAN TERIMA KASIH}

Kegiatan pengabdian kepada masyarakat ini didanai oleh hibah Pengabdian Kepada Masyarakat Stimulus (PKM-S) DIKTI tahun 2019 yang disalurkan melalui LPPM Universitas Islam Indragiri. Untuk itu tim penulis mengucapkan terima kasih kepada Kemenristek-Dikti, LLDIKTI wilayah X dan LPPM Universitas Islam Indragiri. Ucapan yang sama disampaikan pula kepada pengelola jurnal Minda Baharu yang telah berkenan mempublikasikan hasil kegiatan pengabdian ini dan semua pihak yang telah membantu terlaksananya kegiatan pengabdian ini. 


\section{REFERENSI}

Affandi, dan Tang, U. 2002. Fisiologi Hewan Air. Universitas Riau Pres. Riau. 217 hal.

Ariani, N.K.S., Junaedi, M., dan Mukhlis, A. 2018. Penggunaan Berbagai Metode Mutilasi Untuk Membandingkan Lama Waktu Moulting Kepiting Bakau Merah (Scylla olivacea). Jurnal Perikanan Unram. Vol. 8(1): 40-46.

Ario, R., Djunaedi, A., Pratikto, I., Subardjo, P., dan Farida, F. 2019. Perbedaan Metode Mutilasi Terhadap Lama Waktu Molting Scylla serrata. Buletin Oseanografi Marina. Vol 8(2), 103-108.

Aslamyah, S., dan Fujaya, Y. 2014. Frekuensi Pemberian Pakan Buatan Berbasis Limbah Untuk Produksi Kepiting Bakau Cangkang Lunak. Jurnal Administrasi dan Kebijakan Kesehatan Indonesia. Vol. 24(1): 44-52.

Fujaya, Y., Aslamyah, S., Fudjaja, L., dan Alam, N. 2019. Budidaya dan Bisnis Kepiting Lunak: Stimulasi Molting dengan Ekstrak Bayam. Firstbox Media.

Harahap, S.R., Masykur., dan Saputri, M. 2016. Pengaruh Stimulus Mutilasi Pada Organ yang Berbeda Terhadap Kecepatan Moulting Kepiting Bakau (Scylla serrata). Jurnal Perikanan dan Lingkungan. Vol. 6(2).

Harianto, E. 2017. Kinerja Produksi Kepiting Bakau Scylla serrata Cangkang Lunak pada Metode Pemotongan Capit dan Kaki Jalan, Popey, dan Alami. Jurnal Ilmiah Universitas Batanghari Jambi. Vol. 15(1): 15-21.

Iromo, H., Amien, M., dan Suliadi, S. 2019. Studi Budidaya Kepiting Soka (Soft Crab) di Tambak Tradisional Pulau Tarakan Kalimantan Utara. Jurnal Borneo Saintek. Vol. 2(1): 68-73.

Karim, M.Y. 2005. Kinerja Pertumbuhan Kepiting Bakau Betina (Scylla serrata Forsskal) Pada Berbagai Salinitas Media dan Evaluasinya Pada Salinitas Optimum dengan Kadar Protein Pakan Berbeda. Sekolah Pascasarjana. Institut Pertanian Bogor. Bogor.

Katiandagho, B. 2014. Analisis Fluktuasi Parameter Kualitas Air Terhadap Aktifitas Molting Kepiting Bakau (Scylla sp). Agrikan: Jurnal Agribisnis Perikanan. Vol. 7(2): 2125.

Kudsiah, H., Rahim, S.W., Rifa'i, M.A., dan Arwan, A. 2018. Demplot Pengembangan Budidaya Kepiting Cangkang Lunak di Desa Salemba, Kecamatan Ujung Loi, Kabupaten Bulukumba Sulawesi Selatan. Panrita Abdi-Jurnal Pengabdian pada Masyarakat. Vol. 2(2): 151-164.

Qomariyah, L., Samidjan, I., dan Rachmawati, D. 2014. Pengaruh Persentase Jumlah Pakan Buatan yang Berbeda Terhadap Pertumbuhan dan Kelulushidupan Kepiting Bakau (Scylla Paramamosain). Journal of Aquaculture Management and Technology. Vol. 3(4): 18-25. 
Rangka, N.A. 2007. Status Usaha Kepiting Bakau Ditinjau dari Aspek Peluang dan Prospeknya. Jurnal Neptunus. Vol. 14(1): 90-100.

Rangka, N.A., dan Sulaeman. 2010. Pemacuan Pergantian Kulit Kepiting Bakau (Scylla serrata) melalui Manipulasi Lingkungan untuk Menghasilkan Kepiting Lunak. Prosiding Forum Inovasi Teknologi Akuakultur 2010: 179- 185.

Rusmiyati, S. 2011. Sukses Budidaya Kepiting Soka dan Kepiting Telur. Pustaka Baru Press. Yogyakarta. 136 hal.

Sagala, L.S.S., Idris, M., dan Ibrahim, M.N. 2013. Perbandingan Pertumbuhan Kepiting Bakau (Scylla serrata) Jantan dan Betina Pada Metode Kurungan Dasar. Jurnal Mina Laut Indonesia. Vol. 3(12): 46-54.

Samidjan, I., dan Rachmawati, D. 2015. Rekayasa Budidaya Kepiting Bakau Melalui Pemotongan Kaki Jalan Dalam Upaya Peningkatan Produksi Kepiting Soka (Soft Shell). Pena Jurnal Ilmu Pengetahuan Dan Teknologi. Vol. 28(1):103-121.

Sara, L. 1994. Hubungan Kelimpahan Kepiting Bakau, Scylla spp. Dengan Kualitas Habitat di Perairan Segara Anakan, Cilacap (Doctoral dissertation). Tesis Program Pascasarjana Institut Pertanian. Bogor. 80 hal.

Sari, T.E.Y., Usman., Pamungkas, N.A., Idris, M., Sumarto., Yulinda, E., dan Henrik, R. 2019. Pembinaan Masyarakat Desa Untuk Peningkatan Pendapatan Melalui Teknologi Budidaya Kepiting Soka di Desa Pulau Cawan Kecamatan Mandah Kabupaten Indragiri Hilir. Prosiding Seminar Nasional Pemberdayaan Masyarakat. Pekanbaru. Hal 228-234.

Septian, R., Samidjan, I., dan Rachmawati, D. 2013. Pengaruh pemberian Kombinasi Pakan Ikan Rucah dan Buatan yang Diperkaya Vitamin E Terhadap Pertumbuhan dan Kelulushidupan Kepiting Soka (Scylla paramamosain). Journal of Aquaculture Management and Technology. Vol. 2(1): 13-24.

Shelley, C., dan Lovatelli, A. 2011. Mud crab aquaculture: a practical manual. FAO Fisheries and aquaculture technical paper. (567), p.I.

Suswanto, I., dan Munir, A.M.S. 2018. Budidaya Kepiting Soka dengan Metoda Sangkar Massal. Jurnal Pengabdi. Vol. 1(1): 7-16.

Wicaksono, D.L., Zainuri, M., dan Widianingsih, W. 2014. Pengaruh Pemberian Pakan Alami yang Berbeda Terhadap Pertumbuhan Kepiting Soka di Tambak Desa Mangunharjo Kecamatan Tugu. Journal of Marine Research. Vol. 3(3): 265-273.

Widyastuti, Y.R., dan Husni, H. 2007. Pemanfaatan Tambak Udang "Idle" untuk Produksi Kepiting Cangkang Lunak (Soft Shell Crab). Media Akuakultur. Vol. 2(1): 169172. 